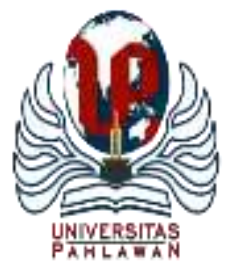

Edukatif : Jurnal Ilmu Pendidikan Volume 4 Nomor 1 Tahun 2022 Halm 590 - 601

EDUKATIF: JURNAL ILMU PENDIDIKAN

Research \& Learning in Education

https:/ledukatif.org/index.php/edukatif/index

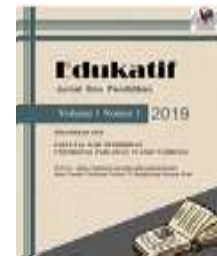

\title{
Pengembangan Instrumen Penilaian Keterampilan Umum Mahasiswa Berbasis Standar Nasional Pendidikan Tinggi (SN-DIKTI)
}

\author{
Muspardi $^{1 凶}$, Yusmanila $^{2}$, Widya ${ }^{3}$ \\ Institut Agama Islam Negeri Batusangkar, Indonesia ${ }^{1}$, \\ Universitas Adzkia, Indonesia ${ }^{2,3}$ \\ E-mail : muspardi@iainbatusangkar.ac.id ${ }^{1}$,yusmanila@ adzkia.ac.id ${ }^{2}$, widya@ adzkia.ac.id ${ }^{3}$
}

\begin{abstract}
Abstrak
Tujuan penelitian ini adalah mengembangkan instrumen penilaian keterampilan umum mahasiswa berbasis Standar Nasional Pendidikan Tinggi (SN-DIKTI). Jenis penelitian ini ialah penelitian pengembangan yang terdiri atas empat tahap, yaitu : (1) pendefinisian, (2) perancangan, (3) pengembangan, (4) penyebaran. Responden penelitian ini adalah dosen STKIP Adzkia pada program studi Pendidikan Guru Sekolah Dasar (PGSD) dan Pendidikan Fisika. Instrumen penelitian berupa angket, lembar wawancara, lembaran uji validitas, lembaran uji praktikalitas. Teknik analisis data yang digunakan dalam penelitian ini analisis kualitatif dan kuantitatif. Hasil penelitian diperoleh nilai validitas instrumen adalah 90,5 dengan kategori sangat valid. Selanjutnya, berdasarkan data respon teman sejawat dan mahasiswa terhadap instrumen penilaian keterampilan umum mahasiswa diperoleh nilai 91 dengan kriteria sangat praktis. Hasil penelitian menunjukkan bahwa instumen penilaian keterampilan umum mahasiswa berbasis Standar Nasional Pendidikan Tinggi (SN-DIKTI) yang dikembangkan telah mencapai kriteria valid dan praktis. Instrumen penilaian keterampilan umum yang hasilkan dapat menjadi acuan oleh dosen dalam menilai keterampilan umum mahasiswa sebagai salah satu aspek yang wajib dinilai oleh dosen.
\end{abstract}

Kata Kunci: Penilaian, Keterampilan Umum; Mahasiswa, SN-DIKTI

\begin{abstract}
The purpose of this study was to pengembangan an instrument for assessing students' general skills based on the National Higher Education Standards (SN-DIKTI). This type of research is pengembanganment research, with four main stages, namely: (1) define, (2) design, (3) develope, (4) disseminate. The respondents of this study were lecturers of the study program of PGSD and Physics Education at STKIP Adzkia. The research instruments were questionnaires, interview sheets, validity test sheets, and practicality test sheets. The data analysis technique used in this study was qualitative and quantitative analysis. The results of the study obtained that the value of the validity of the instrument was 90.5 with a very valid category. Furthermore, based on data on the responses of peers and students to the general skills assessment instrument, students obtained a score of 91 with very practical criteria. The results showed that the general general skills assessment instrument for students based on the National Higher Education Standards (SN-DIKTI) that was developed had reached valid and practical criteria. The general skills assessment instrument produced can be used as a reference by the lecturer in assessing the general skills of students as one of the aspects that must be assessed by the lecturer.
\end{abstract}

Keywords: Evaluation; General Skills; Student; SN-DIKTI

Copyright (c) 2022 Muspardi, Yusmanila, Widya

$\triangle$ Corresponding author

Email : muspardi@iainbatusangkar.ac.id

DOI $\quad:$ https://doi.org/10.31004/edukatif.v4i1.1897

ISSN 2656-8063 (Media Cetak)

ISSN 2656-8071 (Media Online)

Edukatif : Jurnal Ilmu Pendidikan Vol 4 No 1 Tahun 2022 p-ISSN 2656-8063 e-ISSN 2656-8071 
591 Pengembangan Instrumen Penilaian Keterampilan Umum Mahasiswa Berbasis Standar Nasional Pendidikan Tinggi (SN-DIKTI) - Muspardi, Yusmanila, Widya

DOI: https://doi.org/10.31004/edukatif.v4i1.1897

\section{PENDAHULUAN}

Perguruan Tinggi Indonesia di era revolusi industri 4.0 harus benar-benar menerapkan Standar Nasional Pendidikan Tinggi (SN-DIKTI) dengan sungguh-sungguh agar melahirkan lulusan yang berkualitas dan berdaya saing global. Proses Pembelajaran dan penilaian/evaluasi harus mengembangkan kompetensi dan kemampuan peserta didik dalam domain sikap, pengetahuan, dan keterampilan (S. Prihatiningtyas, T. Prastowo, 2013). Proses pembelajaran dilaksanakan agar peserta didik memiliki berbagai sikap, keterampilan, pengetahuan, dan kecakapan hidup (Wicaksono et al., 2016). Sedangkan penilaian adalah salah satu elemen pokok dalam pembelajaran. Tujuan penilaian/evaluasi adalah untuk mengetahui ketercapaian tujuan pembelajaran dan mengetahui efektivitas proses pembelajaran (Wijayanti, 2014). Di dalam SN-DIKTI capaian pembelajaran lulusan yang harus dicapai mahasiswa selama mengikuti jenjang strata-1 meliputi empat aspek capaian, yaitu aspek sikap, pengetahuan, keterampilan umum dan keterampilan khusus. SN-DIKTI merumuskan capaian sikap dan keterampilan umum, sedangkan untuk capaian aspek pengetahuan dan keterampilan khusus harus dirumuskan oleh asosiasi program studi masing-masing.

Pelaksanaan penilaian atau evaluasi dalam pembelajaran harus dikuasai oleh dosen. Evaluasi adalah sesuatu yang terintegrasi dalam proses pembelajaran (Fadhilaturrahmi \& Ananda, 2018). Hal ini sejalan dengan pendapat Rachmawati \& Kurniawati ( 2020) yang menjelaskan bahwa evaluasi merupakan bagian dari proses perkuliahan yang secara keseluruhan kegiatannya tidak dapat dipisahkan dari kegiatan perkulihan. Saat melakukan evaluasi atau penilaian, pendidik membutuhkan alat atau instrumen yang digunakan untuk mengukur kemampuan peserta didiknya. Hal ini juga didukung oleh pendapat (Nisa \& Pahlevi, 2021) yang menyatakan bahwa instrumen penilaian merupakan salah satu bagian penting yang ada dalam proses pembelajaran. Penilaian dapat didefinisikan sebagai upaya merekap capaian pembelajaran yang telah diraih mahasiswa, baik itu capaian sikap, pengetahuan maupun keterampilan. Penilaian sebagai "Suatu proses sistematis yang mengandung pengumpulan informasi, menganalisis dan menginterpretasi informasi tersebut untuk membuat keputusan-keputusan"(Kunandar, 2007).

Permendikbud No 3 Tahun 2020 digunakan sebagai acuan sistem penilaian dalam kurikulum pendidikan tinggi (KPT) yang diartikan sebagai kriteria minimal tentang penilaian proses dan hasil belajar mahasiswa untuk pemenuhan capaian pembelajaran lulusan. Penilaian proses dan hasil belajar mahasiswa terdiri atas: prinsip penilaian, teknik dan instrumen penilaian, mekanisme dan prosedur penilaian, pelaksanaan penilaian, pelaporan penilaian, dan kelulusan mahasiswa.

Teknik penilaian yang beragam harus dilakukan dosen agar penilaian yang dilakukan bisa mengukur semua capaian pembelajaran. Teknik penilaian yang bisa digunakan dosen adalah tes tertulis, penugasan, observasi, tes lisan, jurnal, penilaian portofolio, penilaian diri, dan penilaian antar teman (A.Aziz \& Sapriya, 2011). Dosen dapat memilih teknik penilaian yang tepat sesuai dengan capaian yang akan dinilai, sehingga aspek pengetahuan, sikap, maupun keterampilan umum dan khusus dapat dinilai dengan sistem penilaian yang tepat dan akurat (Muspardi \& Yusri, 2017). Prinsip-prinsip penilaian menurut SN-DIKTI mencakup prinsip edukatif, akuntabel, objektif, otentik,dan transparan yang dilakukan secara terintegrasi.

Sejalan dengan pendapat di atas A.Aziz \& Sapriya, 2011 menyatakan bahwa "Dalam penilaian terdapat beberapa prinsip yang harus diperhatikan, yaitu: sahih, objektif, adil, terpadu, terbuka, menyeluruh dan berkesinambungan, sistematis, beracuan kriteria, dan akuntabel". Instrumen yang bisa digunakan oleh dosen dalam menilai keterampilan umum mahasiswa ialah rubrik, portofolio, jurnal, penialain diri dan penilaian antar teman. Rubrik penilaian merupakan salah satu instrumen penilaian digunakan dosen sebagai alat penilaian dalam proses pembelajaran selama menempuh pendidikan di perguruan tinggi (Suharsimi, 2019). Selanjutnya Illah Sailah, et al., 2014 menguraikan secara konseptual 
592 Pengembangan Instrumen Penilaian Keterampilan Umum Mahasiswa Berbasis Standar Nasional Pendidikan Tinggi (SN-DIKTI) - Muspardi, Yusmanila, Widya

DOI: https://doi.org/10.31004/edukatif.v4i1.1897

rubrik terdiri atas tiga macam bentuk, yaitu (a) Rubrik deskriptif; (b) Rubrik holistik; dan (c) Rubrik skala persepsi.

Instrumen penilaian keterampilan umum mahasiswa yang dijabarkan melalui rumusan dari SNDIKTI belum pernah dikembangkan dan dipublikasikan oleh dosen. Sementara Wicaksono et al., 2016 menyatakan bahwa dosen masih kesulitan melaksanakan penilaian pada aspek sikap dan keterampilan umum mahasiswa terutama pada saat proses penilaian dan pengolahan hasil penilaian.

SN-DIKTI merumuskan sembilan capaian pembelajaran keterampilan umum yang harus dicapai mahasiswa. Penentuan ketercapaian sembilan rumusan keterampilan umum oleh mahasiswa memerlukan penilaian dengan menjabarkan indikator pencapaian masing-masing rumusan tersebut ke dalam bentuk instrumen penilaian yang lebih rinci. Berdasarkan penjelasan Sailah, Illah, dkk (2014) indikator penilaian keterampilan umum berdasarkan SN-DIKTI belum diuraikan secara rinci sehingga dosen diharapkan bisa mengembangkan instrumen penilaian sesuai dengan karakteristik mata kuliah yang di ampunya.

Hasil wawancara dan pengamatan yang dilakukan terhadap dosen dan mahasiswa di STKIP Adzkia diketahui bahwa dosen belum optimal dalam melakukan penilaian keterampilan umum mahasiswa (Muspardi et al., 2020). Dosen atau pendidik mengalami berbagai kesulitan dalam menilai keterampilan umum mahasiswa, baik dalam tahap perencanaan, pelaksananaan dan pelaporan. Penyebab utama dosen kesulitan dalam menilai keterampilan umum mahasiswa adalah belum tersedianya instrumen penilaian keterampilan umum mahasiswa yang mengacu pada SN-DIKTI.

Berdasarkan permasalahan di atas maka penelitian ini ingin menghadirkan solusi terhadap kesulitan yang dialami dosen dalam menilai keterampilan umum yang sesuai dengan capaian yang diharapkan dalam standar nasional pendidikan tinggi. Pengembangan instrumen penilaian keterampilan umum mahasiswa dengan indikator yang rinci dan bisa digunakan oleh semua dosen, sesuai dengan karakteristik mata kuliahnya.

\section{METODE PENELITIAN}

Penelitian ini adalah penelitian pengembangan 4-D (Four-D) yang merupakan model pengembangan perangkat pembelajaran (Thiagarajan, 1974). Tahapan yang dilakukan adalah pendefenisian, perancangan, pengembangan, dan penyebaran. Pada tahap pendefenisian dilakukan langkah-langkah mengidentifikasi masalah, analisis masalah penilaian, analisis problem dosen, analisis SN-DIKTI, serta pemilihan desain/rancangan instrumen penilaian keterampilan umum. Tahap perancangan dilakukan perancangan dengan menetapkan dimensi dan skala, masukan teman sejawat sesama dosen melalui FGD sehingga di peroleh desain/rancangan awal instrumen penilaian keterampilan umum mahasiswa. Tahap pengembangan tindakan yang dilakukan adalah validasi oleh dua orang ahli penilaian/pembelajaran dan ahli bahasa. Selanjutnya dilakukan uji coba dan revisi terhadap hasil validasi sampai diperoleh instrumen penilaian keterampilan umum mahasiswa berbasis SN-DIKTI yang valid dan praktis. Tahap desiminasian, dilakukan penyebaran hasil untuk menguji efektifitas terhadap produk secara terbatas.

Penelitian dilakukan di STKIP Adzkia dengan subjek penelitian ialah dosen dan mahasiswa Program Studi PGSD dan Program Studi Pendidikan Fisika. Instrumen yang dalam penelitian ini adalah angket, lembar validasi ahli dan lembar uji praktikalitas. Angket digunakan untuk mengetahui pelaksanaan penilaian keterampilan umum oleh dosen dan pendapat mahasiswa terhadap penilaian keterampilan umum yang di lakukan dosen. Lembar validasi digunakan untuk mengetahui validitas instrumen penilaian keterampilan umum yang telah dikembangkan. Lembar validitas instrumen penilaian keterampilan umum untuk ahli berisi aspek-aspek yang telah dirumuskan. Setiap aspek dikembangkan menjadi beberapa pernyataan. Skala penilaian pada lembar validitas menggunakan skala 
593 Pengembangan Instrumen Penilaian Keterampilan Umum Mahasiswa Berbasis Standar Nasional Pendidikan Tinggi (SN-DIKTI) - Muspardi, Yusmanila, Widya

DOI: https://doi.org/10.31004/edukatif.v4i1.1897

Likert. Lembar uji praktikalitas dibuat untuk mengetahui praktikalitas penggunaan instrumen penilaian keterampilan umum oleh dosen.

Teknik analisis data yang digunakan dalam penelitian ini analisis kualitatif dan kuantitatif. Lembar validitas dan praktkalitas yang dikembangkan mengacu pada skala Likert, kemudian dikonversi menjadi nilai dengan cara sebagai berikut:

$$
\mathrm{B}=(\mathrm{X} / \mathrm{Y}) \times 100 \%
$$

Dimana $\mathrm{X}=$ skor diisi pada angket, $\mathrm{Y}=$ skor maksimal pada setiap pernyataan, B: tingkat validitas dan Praktikalitas. Untuk mengukur kategori validitas dan praktikalitas dapat dilihat pada tabel 1:

Tabel 1. Kategori validitas dan praktikalitas

\begin{tabular}{ll}
\hline Interval & Kategori \\
\hline $\mathbf{0 - 2 0 \%}$ & Tidak Valid/Tidak Praktis \\
\hline $\mathbf{2 1} \%-\mathbf{4 0} \%$ & Kurang Valid/Kurang Praktis \\
\hline $\mathbf{4 1} \%-\mathbf{6 0} \%$ & Cukup Valid/Cukup Praktis \\
\hline $\mathbf{6 1} \%-\mathbf{8 0} \%$ & Valid/Praktis \\
\hline $\mathbf{8 1} \%-100 \%$ & Sangat Valid/Sangat Praktis \\
\hline Sumber: (Suharsimi, 2019) &
\end{tabular}

\section{HASIL DAN PEMBAHASAN PENELITIAN}

Tahapan yang dilaksanakan pada penelitian ini digambarkan pada gambar 1 .

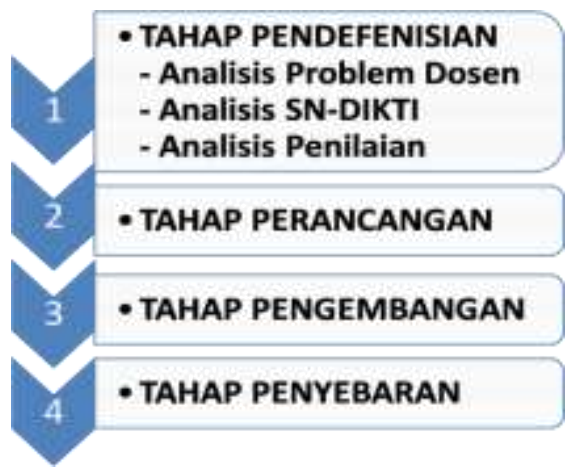

Gambar 1. Tahapan Proses Penelitian

Langkah pertama yang dilakukan pada penelitian ini adalah tahap pendefenisian yang terdiri dari analisis permasalahan dosen, analisis SN-DIKTI, dan analisis penilaian. Hasil analisis ini menjadi data dasar untuk mengembangkan instrumen keterampilan umum mahasiswa. Keterampilan yang telah dimiliki mahasiswa akan sangat menunjang pekerjaan dan aktivitasnya di masa depan (Segara \& Hermansyah, 2019).

Analisis permasalahan dosen dilakukan pada dosen Program Studi Pendidikan Guru dan Sekolah Dasar (PGSD) dan Pendidikan Fisika STKIP Adzkia. Alat yang dipakai untuk mengukur suatu kejadian/keadaan yang akan diteliti disebut instrumen penelitian (Sugiyono, 2017). Instrumen penelitian adalah angket yang diisi oleh dosen lembar wawancara yang dengan dosen. Angket ini mengukur tentang penggunaan instrumen keterampilan umum dalam pembelajaran, permasalahan yang dialami kecenderungan selama ini dosen hanya menilai aspek pengetahuan saja. Umumnya penilaian aspek keterampilan dan sikap yang dilakukan oleh dosen selama ini hanya dengan bersifat perkiraan (Novitasari \& Lisdiana, 2015). 
594 Pengembangan Instrumen Penilaian Keterampilan Umum Mahasiswa Berbasis Standar Nasional Pendidikan Tinggi (SN-DIKTI) - Muspardi, Yusmanila, Widya

DOI: https://doi.org/10.31004/edukatif.v4i1.1897

Berdasarkan hasil analisis dosen diketahui dosen mengalami kesulitan dalam tahap perencanaan, pelaksanaan, dan pelaporan. Persentase dosen yang sudah memiliki instrumen penilaian keterampilan umum adalah $62 \%$, sedangkan $38 \%$ lainnya belum memiliki instrumen penilaian keterampilan umum. Namun, dari $62 \%$ yang sudah memiliki instrumen penilaian ini belum semuanya mengacu pada SN-DIKTI dalam proses pembuatannya (Muspardi et al., 2020).

Selanjutnya berdasarkan hasil analisis, peneliti merancang instrumen penilaian keterampilan umum mahasiswa dengan menjabarkan capaian keterampilan umum dalam SN-DIKTI ke dalam indikator yang konkrit dan rinci dengan mengacu kepada referensi yang terkait dan terbaru. Hasil rancangan yang telah dibuat peneliti diperbaiki dengan adanya diskusi dengan teman sejawat. Hasil dari masukan dari teman sejawat ini dapat menyempurnan isntrumen penilaian katerampilan umum mahasiswa berbasis SN-DIKTI.

Rangkuman analisis dan masukan teman sejawat melalui FGD terhadap instrumen penilaian keterampilan umum mahasiswa dapat dilihat pada tabel 2:

Tabel 2. Pengembangan Instrumen Penilaian Keterampilan Umum Mahasiswa BerbasisSN-DIKTI

\begin{tabular}{|c|c|c|c|c|c|c|}
\hline \multicolumn{4}{|c|}{ Capaian Pembelajaran } & \multirow{3}{*}{ Dimensi } & \multirow{3}{*}{$\begin{array}{c}\text { JENIS } \\
\text { PENILAIAN }\end{array}$} & \multirow[t]{3}{*}{ INSTRUMEN } \\
\hline & \multicolumn{3}{|c|}{ Aspek Sikap } & & & \\
\hline No & KKNI & No & SN-DIKTI & & & \\
\hline 1 & $\begin{array}{l}\text { Mampu } \\
\text { menerapkan } \\
\text { pemikiran logis, } \\
\text { kritis, sistematis, } \\
\text { daninovatif } \\
\text { dalam konteks } \\
\text { pengembangan } \\
\text { atau } \\
\text { implementasi } \\
\text { ilmu } \\
\text { pengetahuan dan } \\
\text { teknologi yang } \\
\text { memperhatikan } \\
\text { dan menerapkan } \\
\text { nilai humaniora } \\
\text { yang sesuai } \\
\text { dengan bidang } \\
\text { keahliannya; }\end{array}$ & & $\begin{array}{l}\text { Mampu } \\
\text { menerapkan } \\
\text { pemikiran logis, } \\
\text { kritis, sistematis, } \\
\text { dan inovatifdalam } \\
\text { konteks } \\
\text { pengembangan } \\
\text { atau implementasi } \\
\text { ilmu pengetahuan } \\
\text { dan teknologi } \\
\text { yang } \\
\text { memperhatikan } \\
\text { dan menerapkan } \\
\text { nilai humaniora } \\
\text { yang sesuaidengan } \\
\text { bidang } \\
\text { keahliannya; }\end{array}$ & $\begin{array}{l}\text { 1. Berpikir } \\
\text { Logis } \\
\text { 2. Berpikir } \\
\text { Kritis } \\
\text { 3. Berpikir } \\
\text { Sistematis } \\
\text { 4. Berpikir } \\
\text { Inovatif }\end{array}$ & $\begin{array}{l}\text { Unjuk kerja } \\
\text { Portofolio }\end{array}$ & 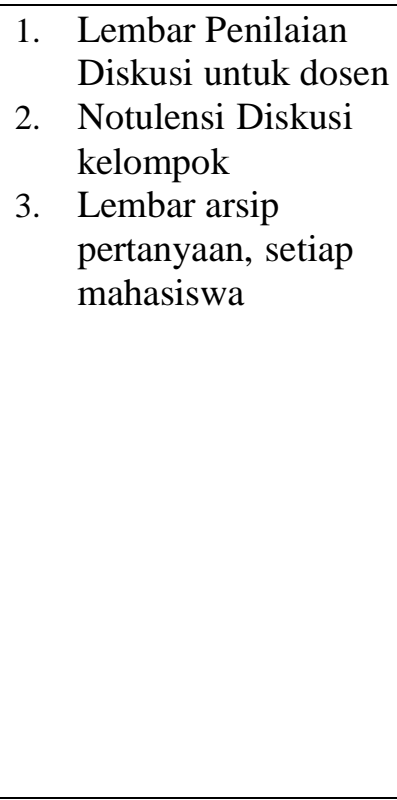 \\
\hline 2 & $\begin{array}{l}\text { Mampu } \\
\text { menunjukkan } \\
\text { kinerjamandiri, } \\
\text { bermutu, dan } \\
\text { terukur; }\end{array}$ & 2 & $\begin{array}{l}\text { Mampu } \\
\text { menunjukkan } \\
\text { kinerja mandiri, } \\
\text { bermutu, dan } \\
\text { terukur; }\end{array}$ & $\begin{array}{l}\text { 1. Kinerja } \\
\text { Mandiri } \\
\text { 2. Kinerja } \\
\text { bermutu } \\
\text { 3. Kinerja } \\
\text { Terukur }\end{array}$ & $\begin{array}{l}\text { Unjuk Kerja } \\
\text { Proyek } \\
\text { Produk } \\
\text { Portofolio }\end{array}$ & $\begin{array}{ll}\text { 1. } & \text { Lembar Penilaian } \\
\text { Proyek citizen/ sosi } \\
\text { al } \\
\text { 2. } \\
\text { Form Penilaian } \\
\text { Video Kreatif }\end{array}$ \\
\hline 3 & $\begin{array}{l}\text { Mampu } \\
\text { mengkaji } \\
\text { implikasi } \\
\text { pengembangan } \\
\text { atau } \\
\text { implementasi } \\
\text { ilmu } \\
\text { pengetahuan } \\
\text { teknologi yang }\end{array}$ & & $\begin{array}{l}\text { Mampu mengkaji } \\
\text { implikasi } \\
\text { pengembangan } \\
\text { atau implementasi } \\
\text { ilmu pengetahuan } \\
\text { teknologiyang } \\
\text { memperhatikan } \\
\text { dan menerapkan } \\
\text { nilai }\end{array}$ & $\begin{array}{l}\text { Keterampilan } \\
\text { Menulis } \\
: \\
\text { a) Ilmiah } \\
\text { b) Non } \\
\text { ilmiah }\end{array}$ & $\begin{array}{l}\text { Proyek } \\
\text { Produk } \\
\text { Portofolio }\end{array}$ & $\begin{array}{l}\text { 1. Form anotasi artikel } \\
\text { bereputasi sebagai } \\
\text { bahan baku } \\
\text { penulisan } \\
\text { skripsi dan karya } \\
\text { ilmiah } \\
\text { 2. Daftar Cek Bukti } \\
\text { Lomba KTIdan } \\
\text { PKM }\end{array}$ \\
\hline
\end{tabular}


595 Pengembangan Instrumen Penilaian Keterampilan Umum Mahasiswa Berbasis Standar Nasional Pendidikan Tinggi (SN-DIKTI) - Muspardi, Yusmanila, Widya

DOI: https://doi.org/10.31004/edukatif.v4i1.1897

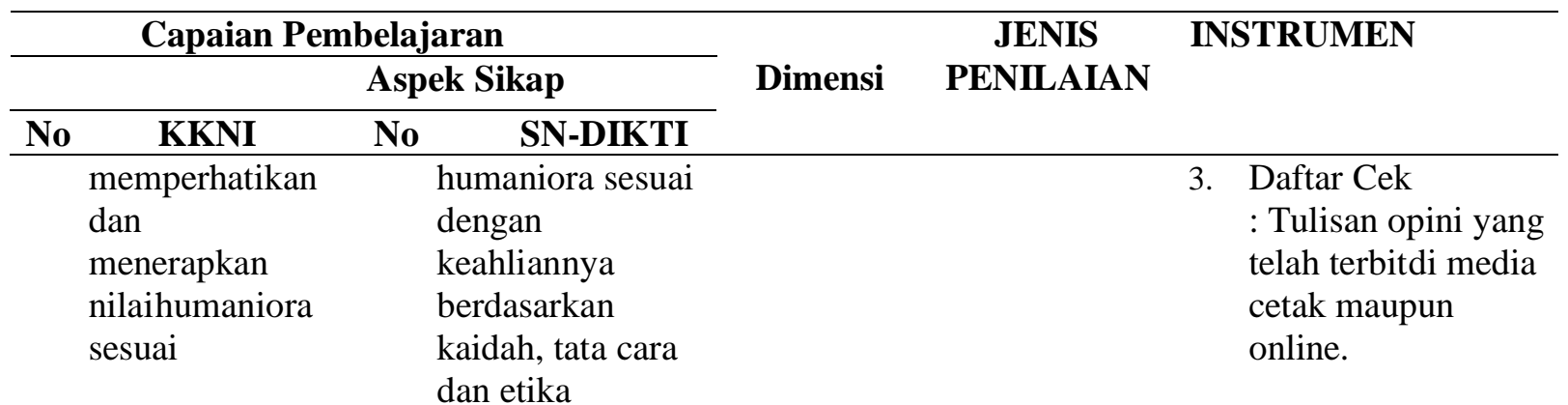

\begin{tabular}{|c|c|c|c|c|c|}
\hline $\begin{array}{l}\text { dengan keahliannya } \\
\text { berdasarkan kaidah, } \\
\text { tata cara dan etika } \\
\text { ilmiah dalam rangka } \\
\text { menghasilkan solusi, } \\
\text { gagasan, desain atau } \\
\text { kritik seni, } \\
\text { menyusundeskripsi } \\
\text { saintifik hasil } \\
\text { kajiannya dalam } \\
\text { bentuk skripsi atau } \\
\text { laporan tugas akhir, } \\
\text { dan mengunggahnya } \\
\text { dalam laman } \\
\text { perguruan tinggi; }\end{array}$ & & $\begin{array}{l}\text { ilmiah dalam rangka } \\
\text { menghasilkan solusi, } \\
\text { gagasan, desain atau } \\
\text { kritik seni, menyusun } \\
\text { deskripsi saintifik } \\
\text { hasil kajiannya dalam } \\
\text { bentukskripsi atau } \\
\text { laporan tugas akhir, } \\
\text { dan mengunggahnya } \\
\text { dalam laman } \\
\text { perguruan tinggi; }\end{array}$ & & & \\
\hline $\begin{array}{l}4 \text { menyusun } \\
\text { deskripsi saintifik } \\
\text { hasil kajiantersebut } \\
\text { di atas dalam bentuk } \\
\text { skripsiatau laporan } \\
\text { tugas akhir, dan } \\
\text { mengunggahnya } \\
\text { dalam laman } \\
\text { perguruan tinggi; }\end{array}$ & 4 & $\begin{array}{l}\text { menyusun deskripsi } \\
\text { saintifik hasil kajian } \\
\text { tersebut di atas dalam } \\
\text { bentuk skripsi atau } \\
\text { laporan tugas akhir, } \\
\text { dan mengunggahnya } \\
\text { dalam laman } \\
\text { perguruantinggi; }\end{array}$ & $\begin{array}{l}\text { Keterampila } \\
\text { n mempub } \\
\text { likasikan } \\
\text { karya Ilmiah }\end{array}$ & $\begin{array}{l}\text { Produk } \\
\text { Proyek } \\
\text { Portofolio }\end{array}$ & $\begin{array}{l}\text { 1. Form anotasi } \\
\text { artikel } \\
\text { bereputasi } \\
\text { sebagai bahan } \\
\text { baku } \\
\text { penulisan } \\
\text { skripsi dan } \\
\text { karya ilmiah } \\
\text { 2. Daftar Cek } \\
\text { Bukti Lomba } \\
\text { KTI dan } \\
\text { PKM } \\
\text { 3. Daftar Cek: } \\
\text { Tulisan opini } \\
\text { yang telah } \\
\text { terbit di } \\
\text { media cetak } \\
\text { maupun } \\
\text { online. } \\
\text { 4. Form bukti } \\
\text { publikasi } \\
\text { serta urlnya. }\end{array}$ \\
\hline
\end{tabular}


596 Pengembangan Instrumen Penilaian Keterampilan Umum Mahasiswa Berbasis Standar Nasional Pendidikan Tinggi (SN-DIKTI) - Muspardi, Yusmanila, Widya

DOI: https://doi.org/10.31004/edukatif.v4i1.1897

\begin{tabular}{|c|c|c|c|c|c|}
\hline \multicolumn{3}{|c|}{ Capaian Pembelajaran } & \multirow{3}{*}{ Dimensi } & \multirow{3}{*}{$\begin{array}{c}\text { JENIS } \\
\text { PENILAIAN }\end{array}$} & \multirow[t]{3}{*}{ INSTRUMEN } \\
\hline \multicolumn{3}{|c|}{ Aspek Sikap } & & & \\
\hline KKNI & No & SN-DIKTI & & & \\
\hline $\begin{array}{l}5 \text { mampu mengambil } \\
\text { keputusan secara } \\
\text { tepat dalam konteks } \\
\text { penyelesaian } \\
\text { masalah di bidang } \\
\text { keahliannya, } \\
\text { berdasarkan hasil } \\
\text { analisis informasi } \\
\text { dan data; }\end{array}$ & 5 & $\begin{array}{l}\text { mampu mengambil } \\
\text { keputusan secara tepa } \\
\text { dalam konteks } \\
\text { penyelesaian masalah } \\
\text { di bidang keahliannya } \\
\text { berdasarkan hasil } \\
\text { analisis informasi dan } \\
\text { data; }\end{array}$ & $\begin{array}{ll} & \text { Keteram } \\
\text { at } & \text { pilan } \\
& \text { mengamb } \\
\mathrm{h} & \text { keputus ar } \\
\text { a, } & \text { yang } \\
& \text { bijaksan } \\
\text { n } & \text { a/literasi } \\
& \text { data dan } \\
& \text { informa si }\end{array}$ & $\begin{array}{l}\text { Unjuk kerja } \\
\text { Proyek }\end{array}$ & $\begin{array}{l}\text { Lembar kinerja } \\
\text { kelompok }\end{array}$ \\
\hline $\begin{array}{l}6 \text { mampu memelihara } \\
\text { dan mengembang- } \\
\text { kan jaringan kerja } \\
\text { dengan } \\
\text { pembimbing,kolega, } \\
\text { sejawat baik di } \\
\text { dalam maupun di } \\
\text { luar lembaganya; }\end{array}$ & 6 & $\begin{array}{l}\text { mampu memelihara } \\
\text { dan mengembang-kan } \\
\text { jaringan kerja dengan } \\
\text { pembimbing, kolega, } \\
\text { sejawat baik di dalam } \\
\text { maupun di luar } \\
\text { lembaganya; }\end{array}$ & $\begin{array}{ll}\text { Keteram } \\
\text { in } & \text { pilan } \\
\text { n } & \text { berkolab } \\
\text { n } & \text { orasi } \\
& \\
\end{array}$ & $\begin{array}{l}\text { Unjuk Kerja } \\
\text { Proyek } \\
\text { Produk } \\
\text { Portofolio }\end{array}$ & $\begin{array}{l}\text { Form Penilaian } \\
\text { diri sendiri dan } \\
\text { antar teman } \\
\text { (dosen } \\
\text { memastikan } \\
\text { kerja di bagi } \\
\text { secara adil) }\end{array}$ \\
\hline $\begin{array}{l}7 \text { Mampu } \\
\text { bertanggungjawab }\end{array}$ & 7 & $\begin{array}{l}\text { Mampu } \\
\text { bertanggungjawab ata }\end{array}$ & $\begin{array}{ll} & 1 . \\
\text { as Bertang } \\
\text { ang }\end{array}$ & $\begin{array}{l}\text { Unjuk kerja } \\
\text { Proyek }\end{array}$ & $\begin{array}{l}\text { Penilaian diri } \\
\text { sendiri dan } \\
\text { anter }\end{array}$ \\
\hline $\begin{array}{l}\text { atas pencapaian } \\
\text { hasilkerja } \\
\text { kelompok dan } \\
\text { melakukan } \\
\text { supervisi dan } \\
\text { evaluasi } \\
\text { terhadap } \\
\text { penyelesaian } \\
\text { pekerjaan yang } \\
\text { ditugaskan } \\
\text { kepada pekerja } \\
\text { yang berada di } \\
\text { bawah } \\
\text { tanggungjawabn } \\
\text { ya; }\end{array}$ & & $\begin{array}{l}\text { pencapaian hasil } \\
\text { kerja kelompok dan } 2 \\
\text { melakukan supervisi } \\
\text { dan evaluasi } \\
\text { terhadap } \\
\text { penyelesaian } \\
\text { pekerjaanyang } \\
\text { ditugaskan kepada } \\
\text { pekerja yang berada } \\
\text { di bawah } \\
\text { tanggungjawabnya; }\end{array}$ & $\begin{array}{l}\text { Jawab } \\
\text { 2. Keteram } \\
\text { pilan } \\
\text { dalam } \\
\text { memim } \\
\text { pin }\end{array}$ & $\begin{array}{l}\text { Produk } \\
\text { portofolio }\end{array}$ & $\begin{array}{l}\text { teman } \quad \text { dosen } \\
\text { memastikan kerja di } \\
\text { bagi secara adil) }\end{array}$ \\
\hline $\begin{array}{l}8 \text { Mampu } \\
\text { melakukan } \\
\text { proses evaluasi } \\
\text { diri terhadap } \\
\text { kelompok kerja } \\
\text { yang berada } \\
\text { dibawah } \\
\text { tanggung } \\
\text { jawabnya, }\end{array}$ & 8 & $\begin{array}{l}\text { Mampu melakukan } \mathrm{F} \\
\text { proses evaluasi diri } \mathrm{F} \\
\text { terhadap kelompok } \mathrm{F} \\
\text { kerja yang berada } \\
\text { dibawah tanggung } \\
\text { jawabnya, dan } \\
\text { mampumengelola } \\
\text { pembelajaran secara } \\
\text { mandiri; dan }\end{array}$ & $\begin{array}{l}\text { Keteram } \\
\text { pilan } \\
\text { Reflektif }\end{array}$ & $\begin{array}{ll}\text { Unjuk Kerja } & \mathrm{F} \\
\text { Portofolio } & \mathrm{c} \\
& \mathrm{b}\end{array}$ & $\begin{array}{l}\text { Form bukti rekfleksi } \\
\text { dalampembelajaran dan } \\
\text { berkelompok }\end{array}$ \\
\hline $\begin{array}{l}\text { dan mampu } \\
\text { mengelola } \\
\text { pembelajaran } \\
\text { secara mandiri; }\end{array}$ & & & & & \\
\hline
\end{tabular}


597 Pengembangan Instrumen Penilaian Keterampilan Umum Mahasiswa Berbasis Standar Nasional Pendidikan Tinggi (SN-DIKTI) - Muspardi, Yusmanila, Widya

DOI: https://doi.org/10.31004/edukatif.v4i1.1897

\begin{tabular}{|c|c|c|c|c|c|c|}
\hline \multicolumn{4}{|c|}{ Capaian Pembelajaran } & \multirow{3}{*}{ Dimensi } & \multirow{3}{*}{$\begin{array}{c}\text { JENIS } \\
\text { PENILAIAN }\end{array}$} & \multirow[t]{3}{*}{ INSTRUMEN } \\
\hline & & Asp & kap & & & \\
\hline No & KKNI & No & SN-DIKTI & & & \\
\hline
\end{tabular}

\begin{tabular}{|c|c|c|c|c|c|c|}
\hline 9 & $\begin{array}{l}\text { Mampu } \\
\text { mendokumentasi } \\
\text { kan,menyimpan, } \\
\text { mengamankan, } \\
\text { dan menemukan } \\
\text { kembalidata } \\
\text { untuk menjamin } \\
\text { kesahihan dan } \\
\text { mencegah } \\
\text { plagiasi. }\end{array}$ & 9 & $\begin{array}{l}\text { Mampu } \\
\text { mendokumentasikan } \\
\text {,menyimpan, } \\
\text { mengamankan, dan } \\
\text { menemukan } \\
\text { kembalidata untuk } \\
\text { menjaminkesahihan } \\
\text { dan mencegah } \\
\text { plagiasi. }\end{array}$ & $\begin{array}{l}\text { Keteram } \\
\text { pilan } \\
\text { Mendok } \\
\text { umentas } \\
\text { ikan } \\
\text { menggu } \\
\text { nakan } \\
\text { Cloud dan } \\
\text { manual. }\end{array}$ & $\begin{array}{l}\text { Portofolio } \\
\text { produk }\end{array}$ & $\begin{array}{l}\text { Form bukti } \\
\text { Mahasiswa memiliki } \\
\text { google drive } \\
\quad \text { yangterkelola } \\
\text { dengan rapi untuk } \\
\text { penyimpanan data }\end{array}$ \\
\hline $\begin{array}{l}\mathrm{Su} \\
\mathrm{m} \\
\mathrm{be} \\
\mathrm{r}\end{array}$ & $\begin{array}{l}\text { Lampiran } \\
\text { Perpres nomor } 8 \\
\text { tahun } 2012 \\
\text { tentang } \\
\text { Kerangka } \\
\text { Kualifikasi } \\
\text { Nasional } \\
\text { Indonesia } \\
\text { (Presiden } \\
\text { Republik } \\
\text { Indonesia, 2012) }\end{array}$ & $\begin{array}{l}\text { Lar } \\
\text { No } \\
\text { ten } \\
\text { Per } \\
\text { Ke } \\
\text { dan } \\
\text { Re } \\
202\end{array}$ & $\begin{array}{l}\text { piran Permendikbud } \\
\text { hor } 3 \text { tahun } 2020 \\
\text { angStandar Nasional } \\
\text { didikan Tinggi } \\
\text { menterian Pendidikan } \\
\text { Kebudayaan } \\
\text { ublik Indonesia, } \\
\text { j) }\end{array}$ & & & \\
\hline
\end{tabular}

Tahap selanjutnya adalah tahap pengembangan yaitu uji validitas dan praktikalitas terhadap instrumen keterampilan umum mahasiswa berbasis SN-DIKTI. Validasi Instrumen penilaian keterampilan umum mahasiswa dilakukan untuk melihat apakah instrumen penilaian keterampilan umum mahasiswa yang dikembangkan sudah valid, baik dari segi isi, kesesuaian dengan prinsip-prinsip penilaian, kebahasaan dan tampilan. Hasil validasi dari instrumen penilaian keterampilan umum mahasiswa dapat diamati pada Tabel 3 berikut.

Tabel 3. Hasil Validasi Pertama Instrumen Penilaian Keterampilan Umum Mahasiswa

\begin{tabular}{lll}
\hline Validator & $\begin{array}{c}\text { Penilaian } \\
(\%)\end{array}$ & \multicolumn{1}{c}{ Kesimpulan / Saran } \\
\hline & 1) & $\begin{array}{l}\text { Ada beberapa kesalahan pengejaan di beberapa } \\
\text { bagian (seperti judul utama "instrumen"- } \\
\text { "penilaian" }\end{array}$ \\
& 2) $\begin{array}{l}\text { Hindari menggunakan kata sambung "dan/atau" } \\
\text { yang mana pada dasarnya dapat membuat } \\
\text { kerancuan dalam penilaian. Sebagai contoh : } \\
\text { Penyajian materi menarik dan mudah dipahami. } \\
\text { Disini ada dua makna } \\
\text { yang bisa ditangkap, keraguan dapat terjadi }\end{array}$ \\
& 82 &
\end{tabular}




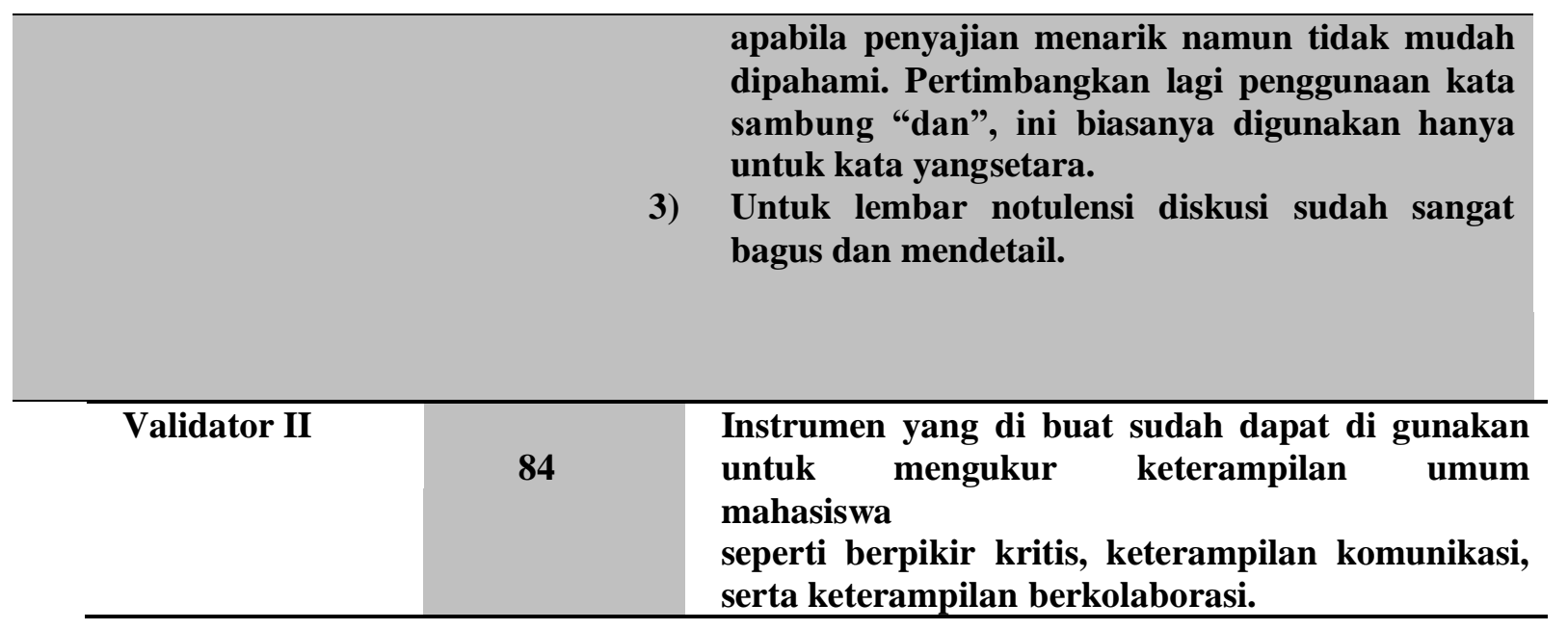

Tabel 3 menunjukkan bahwa instrumen penilaian keterampilan umum mahasiswa memiliki persentase rata-rata sebesar $83 \%$ dengan kategori sangat valid. Akan tetapi, perlu dilakukan revisi sesuai dengan saran validator. Setelah instrumen penilaian keterampilan umum mahasiswa tersebut direvisi, maka dilakukan validasi kembali. Hasil validasi terhadap instrumen penilaian keterampilan umum mahasiswa yang telah direvisi ditampilkan dalam Tabel 4:

Tabel 4. Hasil Validasi Kedua Instrumen Penilaian Keterampilan Umum Mahasiswa

\begin{tabular}{ccc}
\hline Validator & Penilaian $(\%)$ & Kategori \\
\hline Validator I & 90 & Sangat valid \\
\hline Validator II & 91 & Sangat valid \\
\hline
\end{tabular}

Tabel 4 menunjukkan bahwa Instrumen penilaian keterampilan umum mahasiswa memiliki persentase rata-rata sebesar 90,5 \% dengan kategori sangat valid. Instrumen penilaian keterampilan umum mahasiswa yang telah valid ini selanjutnya dapat digunakan dalam pelaksanaan penilaian perkuliahan.

Instrumen penilaian keterampilan umum mahasiswa penilaian yang dibuat bisa dijadikan sebagai alat penilaian untuk mengukur keterampilan umum mahasiswa dalam proses penilaian perkuliahan. Dengan adanya instrumen penilaian keterampilan umum mahasiswa maka akan memotivasi dan mendorong mahasiswa dalam meningkatkan kualitas pembelajarannya karena transparansi penilaian yang dilakukan melalui intrumen penilaian. Instrumen penilaian keterampilan umum mahasiswa yang digunakan harus valid sehingga layak digunakan dalam proses perkuliahan. Pada penelitian ini, uji validitas dilakukan dari aspek isi, konstruk, dan bahasa. Dengan demikian, instrumen penilaian keterampilan umum mahasiswa yang digunakan dalam kegiatan perkuliahan telah valid.

Validasi instrumen penilaian keterampilan umum mahasiswa dilakukan sebanyak dua kali. Pada validasi pertama ditemukan beberapa kekurangan dari instrumen penilaian keterampilan umum mahasiswa yang dirancang baik dalam segi isi maupun tampilan instrumen penilaian keterampilan umum mahasiswa. Sehingga, instrumen penilaian keterampilan umum mahasiswa tersebut direvisi berdasarkan saran validator. Hasil revisi ini kemudian divalidasi kembali sehingga diperoleh instrumen penilaian keterampilan umum mahasiswa dengan kategori sangat valid dengan nilai 90,5\%.

Selanjutnya dilakukan uji praktikalitas pada teman sejawat dan mahasiswa. Berdasarkan hasil analisis data tentang respon teman sejawat mahasiswa terhadap instrumen penilaian keterampilan umum yang dikembangkan dapat dilihat pada tabel 5 : 
Tabel 5. Hasil Respon teman sejawat dan Mahasiswa terhadap instrumen Penilaian Keterampilan Umum Mahasiswa

\begin{tabular}{llrr}
\hline No & Aspek yan Diukur & Nilai & Kriteria \\
\hline 1 & Aspek Manfaat & 93 & Sangat Praktis \\
\hline 2 & $\begin{array}{l}\text { Aspek Petunjuk } \\
\text { Penggunaan }\end{array}$ & 90 & Sangat Praktis \\
\hline 3 & $\begin{array}{l}\text { Aspek Bahasa dan } \\
\text { Tampilan }\end{array}$ & 90 & Sangat Praktis \\
\hline \hline Rata-rata keseluruhan & 91 & Sangat Praktis
\end{tabular}

Berdasarkan data respon teman sejawat dan mahasiswa terhadap instrumen penilaian keterampilan umum mahasiswa diketahui sangat praktis. Nilai ini deperoleh karena instrumen yang dikembangkan sangat jelas dan mudah dipahami sehingga memudahkan teman sejawat merekap penilaian mahasiswa serta mahasiswa makin termotivasi untuk meningkatkan kualitas pembelajarannya.

Perbedaan persepsi, kemampuan dan instrumen antara dosen satu dengan yang lain menyebabkan penilaian yang dilakukan dosen belum objektif dan akuntabel (Sri Hartini, 2019). Oleh kerana itu, dengan ditemukannya instrumen penilaian keterampilan umum mahasiswa berbasis SN-DIKTI yang telah memenuhi kriteria valid dan praktis bisa digunakan oleh dosen. Selanjutnya instrumen penilaian keterampilan umum yang valid dan praktis disebarkan kepada dosen lain di Universitas Adzkia dan juga dosen di kampus lain. Temuan ini sejalan dengan hasil penelitian Haris (2019) yang menegaskan bahwa perguruan tinggi dituntut untuk menghasilkan lulusan yang bermutu dan memiliki berbagai keterampilan yang relevan untuk kepentingan dan kemajuan bangsa.

Keterbatasan penelitian ini, pada tahap penyebaran belum begitu optimal karena masih dilakukan secara terbatas serta belum dibuat dalam bentuk aplikasi yang bisa diunduh melalui playstore. Peneliti akan melakukan pengembangan lebih lanjut sesuai dengan perkembangan keilmuan dan kemajuan teknologi.

\section{KESIMPULAN}

Penelitian ini menggunakan model pengembangan 4-D dengan 4 tahaapan yaitu tahap define, design, develope, dan dessimination. Pada tahap define dilakukan langkah-langkah mengidentifikasi masalah, analisis masalah penilaian, analisis problem dosen, analisis SN-DIKTI, serta pemilihan desain/rancangan instrumen penilaian keterampilan umum. Tahap design dilakukan perancangan dengan menetapkan dimensi dan skala, masukan teman sejawat sesama dosen melalui FGD sehingga di peroleh desain/rancangan awal instrumen penilaian keterampilan umum mahasiswa. Tahap develop tindakan yang dilakukan adalah validasi oleh dua orang ahli penilaian/pembelajaran dan ahli bahasa. Selanjutnya dilakukan uji coba dan revisi terhadap hasil validasi sampai diperoleh instrumen penilaian keterampilan umum mahasiswa yang valid dan praktis. Tahap dessimination, dilakukan penyebaran secara terbatas. Padan penelitian telah dihasilakan instrumen penilian keterampilan umum mahasiswa berbasis SN-DIKTI yang sangat valid dan sangat praktis sehingga bisa digunakan dalam pelaksanaan penilaian keterampilan umum mahasiswa oleh dosen.

\section{UCAPAN TERIMA KASIH}

Pada kesempatan ini peneliti menyampaikan rasa terima kasih yang sebesar-besarnya dan penghargaan yang setinggi-tingginya kepada Kemendikbud DIKTI yang telah memberikan bantuan hibah dalam pelaksanaan penelitian ini. Selanjutnya peneliti menyampaikan terima kasih kepada Ketua STKIP Adzkia dan kepada semua pihak yang telah banyak membantu dalam proses penelitian dan penyusunan artikel ini. 
600 Pengembangan Instrumen Penilaian Keterampilan Umum Mahasiswa Berbasis Standar Nasional Pendidikan Tinggi (SN-DIKTI) - Muspardi, Yusmanila, Widya

DOI: https://doi.org/10.31004/edukatif.v4i1.1897

\section{DAFTAR PUSTAKA}

A.Aziz, W., \& Sapriya. (2011). Teori Dan Landasan Pendidikan Kewarganegaraan. Cv Alfabeta.

Fadhilaturrahmi, F., \& Ananda, R. (2018). Evaluasi Pembelajaran Ips Berbasis Taksonomi Bloom Dua Dimensi Di Sekolah Dasar. Jurnal Basicedu, 1(2), 12-21. Https://Doi.Org/10.31004/Basicedu.V1i2.2

Haris, A. (2019). Penerapan Kurikulum Berbasis Kkni Pada Program Studi Pendidikan Agama Islam. AlFurqan, 7(2), 63-81.

Illah Sailah, Et Al. (2014). Buku Panduan Kurikulum Pendidikan Tinggi. 1-104.

Kementerian Pendidikan Dan Kebudayaan Republik Indonesia. (2020). Peraturan Menteri Pendidikan Dan Kebudayaan Nomor 03 Tahun 2020 Tentang Standar Nasional Perguruan Tinggi. 1.

Kunandar. (2007). Guru Profesional. Pt Raja Grafindo Persada.

Muspardi, M., \& Yusri, R. (2017). Prosiding Seminar Nasional Pengembangan Pendidikan Tinggi Ke-Iii (Snppt Iii) "Peningkatan Kualitas Pendidikan Tinggi Menuju Institusi Unggul Dan Berdaya Saing". Pengembangan Rubrik Penilaian Sikap Berbasis Kkni Dan Sn-Dikti, 27-55.

Muspardi, Yusmanila, \& Desmariani, E. (2020). Problematika Dosen Dalam Menggunakan Instrumen Penilaian Pendidikan Keterampilan Umum Mahasiswa Berbasis Standar Nasional Tinggi (Sn-Dikti). Jurnal Education And Development, 8(4), 54-58.

Nisa, S., \& Pahlevi, T. (2021). Pengembangan Instrument Penilaian Hots Berbantuan Quizizz Pada Mata Pelajaran Kearsipan Smk. Edukatif: Jurnal Ilmu Pendidikan, 3(5), 2146-2159. Https://Edukatif.Org/Index.Php/Edukatif/Article/View/756

Novitasari, S., \& Lisdiana. (2015). Pengembangan Instrumen Penilaian Ranah Afektif Dan Psikomotorik Pada Mata Kuliah Praktikum Struktur Tubuh Hewan. 4(1), 97-103.

Presiden Republik Indonesia. (2012). Peraturan Presiden Nomor 8 Tahun 2012 Tentang Kerangka Kualifikasi Nasional Indonesia.

Rachmawati, R., \& Kurniawati, A. (2020). Pengembangan Instrumen Penilaian Tes Berbasis Mobile Online Pada Prodi Pendidikan Matematika. Prima: Jurnal Pendidikan Matematika, 4(1), 46-63. Https://Doi.Org/10.31000/Prima.V4i1.1891

S. Prihatiningtyas, T. Prastowo, B. J. (2013). Jurnal Pendidikan Ipa Indonesia Imlementasi Simulasi Phet Dan Kit Sederhana Untuk Mengajarkan Keterampilan Psikomotor Siswa Pada Pokok Bahasan Alat Optik. Jurnal Pendidikan Ipa Indonesia, 2(1), 18-22.

Segara, N. B., \& Hermansyah. (2019). Online Peer Assessment Untuk Mengembangkan Keterampilan Presentasi Oral Diskusi Kelompok Kecil Pada Pembelajaran Ips. 28(2), 139-151. Https://Ejournal.Upi.Edu/Index.Php/Jpis/Article/View/20191/Pdf

Sri Hartini, H. H. (2019). Analisis Sinkronitas Rencana Pembelajaran Semester (Rps) Dengan Rencana Tugas Semester Mahasiswa (Rtm) Dan Rencana Evaluasi Pembelajaran (Rep) Dosen Fkip Unisri Tahun 2018. Journal Of Chemical Information And Modeling, 3(9), 608-621. Https://Doi.Org/10.1017/Cbo9781107415324.004

Sugiyono. (2017). Metode Penelitian Kuantitatif, Kualitatif, Dan R\&D. Cv Alfabeta.

Suharsimi, A. (2019). Prosedur Penelitian. In Rineka Cipta. Cv. Rumahkayu Pustaka Utama.

Thiagarajan, S. (1974). Instructional Pengembanganment For Training Teachers Of Exceptional Children. In A Sourcebook.

Wicaksono, T. P., Muhardjito, \& Harsiati, T. (2016). Pengembangan Penilaian Sikap Dengan Teknik Observasi , Self Assessment, Dan Peer Assessment Pada Pembelajaran Tematik Kelas V Sdn Arjowinangun 02 Malang. Jurnal Pendidikan: Teori, Penelitian, Dan Pengembangan, 1(1), 45-51. Http://Journal.Um.Ac.Id/Index.Php/Jptpp/Article/View/5214 
601 Pengembangan Instrumen Penilaian Keterampilan Umum Mahasiswa Berbasis Standar Nasional Pendidikan Tinggi (SN-DIKTI) - Muspardi, Yusmanila, Widya

DOI: https://doi.org/10.31004/edukatif.v4i1.1897

Wijayanti, A. (2014). Pengembangan Autentic Assesment Berbasis Proyek Dengan Pendekatan Saintifik Untuk Meningkatkan Keterampilan Berpikir Ilmiah Mahasiswa. Jurnal Pendidikan Ipa Indonesia, 3(2), $102-108$. 